\title{
BUDGETING PROCESS IN TOURISM COMPANIES FOR THE PURPOSE OF IMPROVING THE QUALITY OF TOURISM PRODUCTS
}

\section{Danica Vuković}

Singidunum University, PhD candidate, Belgrade, Serbia
Correspondence:

Danica Vuković

e-mail:

danica.vukovic.13@singimail.rs

\begin{abstract}
:
Deciding on a travel agency's budget is a highly complex task. Budgeting process in the travel agency is directly linked to the planning process, which needs to improve the decision-making process through formalization of the planning process. Travel agency's objectives and methods for meeting those objectives are defined in the planning process, starting from the internal and external factors that are of particular importance when making a series of decisions in the process of strategic and operational planning. When formulating general budget, the rational aspect of decision-making predominates when it comes to the quality improvement of a tourism product, although other decisionmaking aspects are implemented by an agency in accordance with its financial and human resources, and time as a resource, should not be ignored. Scientific decision-making requires greater financial resources. There is also intuitive decision making in case the agency performs an independent assessment of the market, relying on its previous business experience. In the final phase of the general budget formulation, new decisions are made based on the budgeted balance sheet, which determines further business policy of the agency, no matter if the proposed budget will be accepted or revised.
\end{abstract}

Keywords:

budgeting, planning, quality improvement, general budget, management.

\section{INTRODUCTION}

The budget is a financial plan which covers a specific period of time, while the budget development process is called budgeting. Budgeting is used as a "forecasting technique, planning and control instrument." Budgeting process includes three phases: planning, control and audit (Stanišić \& Radović, 2011, p. 2).

Decision-making is the beginning of the activities of every manager in tourism sector. There are different forms of decision-making in the management. They can be viewed from several aspects, holders or participants in the decision-making, depending on the facts available at that particular moment of the decision-making process, so we distinguish the following (Zečević \& Nedeljković, 2000, p. 54):

- From the standpoint of methods: intuitive, rational and scientific decision-making

- From the standpoint of the number of participants: individual and group decision-making. 


\section{GENERAL BUDGET}

Nowadays, there are different definitions of decision-making process. For a large number of authors, the decision-making process includes the problem solving process with the aim to execute an action. The key element of decision-making process is a choice between possible alternative activities (Kickert, 1980). The choice can be made through a systematic approach to the decision-making process. It involves the application of different rules and decision-making techniques, which are based on a set of methods and procedures essential for problem solving, such as diagnostic and simulation techniques. In addition, decision-making skills are significant too, which represent the effective use of knowledge in practice.

A company's management should successfully forecast future conditions under which the company will operate. Planning future actions in a quantitative manner is done by drafting the general budget. Daily operational issues preoccupy management, thus drawing their attention from future targeted activities to the current business operations. Budgeting opposes this tendency making the planning process an explicit responsibility of the management.

The planning phase includes the collection of necessary data defining the goals for a certain period of time. Control or monitoring phase includes the comparison between the planned and actual revenues and expenditures. The budget audit is done at the end of the year, indicating the positive and negative aspects of the current budget and creating a high-quality analytical basis for the new budget draft.

The general budget consists of a number of budgets which jointly express planned activities of the company. The number and preparation of the budget included in the general budget depend on the size and complexity of the company. The general budget typically includes operational and financial budgets (Čerović \& Spasić, 2013, p. 222). Operating budgets are: sales and service revenues budget, production budget, budget required for raw materials procurement, production and sales cost budget, administrative cost budget and marketing budget. Financial budgets include balance sheet and income statement budget, cash flow budget and investments budget (capital budget).

The mere preparation of the budget of tourism organization for the purpose of improving the quality of tourism products should be centrally managed. Budget commission consisting of either department heads or other senior executives usually deals with it, and is a form of group decision-making. The advantage of such decision-making lies in better overall knowledge and top quality decision-making, while the disadvantage lies in denying their own responsibility and the need of an individual to be in agreement with others, which may delay the decision-making process. The second procedure is that a top manager, without consulting subordinates, drafts the general budget. The case of individual decision-making is rare in practice and implies the increased level of risk and responsibility. The achieved business result is recognised through the comparison between the current balance sheet and income statement that covers the same period of the previous year. The rate between the two aforementioned shows whether the trends and developments that existed in the economy are still present and whether there has been a positive change or stagnation in business. The comparison and analysis of these two statements, as well as drawing conclusions based on them, fall within the domain of rational decision-making.

The main budget of the tourist agency in our case is prepared monthly, while the budgeted balance sheet is prepared quarterly. The balance sheet at the end of the accounting period, given in the table below, is the foundation for general budget preparation:

Travel agency

Balance sheet as of June 30, 2015.

\begin{tabular}{|c|c|c|c|}
\hline \multicolumn{2}{|c|}{ Active } & \multicolumn{2}{|c|}{ Passive } \\
\hline Cash & $€ 100.000$ & Suppliers & $€ 200.000$ \\
\hline Customers & 150.000 & \multirow{2}{*}{$\begin{array}{l}\text { Calculated } \\
\text { income tax to } \\
\text { pay on July } 15 \\
2015 .\end{array}$} & \multirow{2}{*}{100.000} \\
\hline Supplies & 100.000 & & \\
\hline Equipment & 500.000 & Ordinary shares & 400.000 \\
\hline $\begin{array}{l}\text { Accumulated } \\
\text { depreciation }\end{array}$ & $(100.000)$ & $\begin{array}{l}\text { Retained } \\
\text { earnings }\end{array}$ & 50.000 \\
\hline Total & $€ 750.000$ & Total & $€ 750.000$ \\
\hline
\end{tabular}

\section{OPERATING BUDGETS}

\section{Sales revenue budget}

The first segment of the general budget drafted in the company is a sales revenue budget that affects further budgeting segments and is the basis for the next phases of budget drafting. The budget drafting starts from the sales forecasts. Therefore, sales budget arises from the forecasted sales volume, the capacity of the company 
itself, the forecasted sales costs (e.g. advertising campaigns). As the application of forecasting involves the use of mathematical and statistical methods, including the use of information technology, drafting of the budget is a form of scientific decision-making. Depending on the business policy and available resources, the company may prepare the budget either independently or through a specialized company and conduct research of public opinion, market and market evaluation. In case the company lacks resources to carry out scientific methods when drafting sales budget, it relies on sales budgets from the previous period. It could be said that it is a form of intuitive decision-making, because it primarily relies on the previous experiences.

The sales budget formulation based on rational decision-making, starting from the achieved level of sales volume in June, as shown in table below, comes after the completion of the sales forecasting phase through the application of scientific methods.

\begin{tabular}{lccc}
\hline & \multicolumn{3}{c}{$\begin{array}{c}\text { Budget travel agency sales } \\
\text { July - September } 2015\end{array}$} \\
\hline Month & Quantity & Price $€$ & Total $€$ \\
\hline June & 30.000 & 10 & 300.000 \\
\hline July & 25.000 & 10 & 250.000 \\
\hline August & 22.000 & 10 & 220.000 \\
\hline September & 25.000 & 10 & 250.000 \\
\hline October & 20.000 & 10 & 200.000 \\
\hline
\end{tabular}

\section{Procurement budget}

All other budgets after the sales budget have dependent items. The aim of procurement budget is that the company has enough, but not too much, goods and services in order to avoid the "freezing" of liquid assets. On the other hand, making a profit is crucial, but at the same time, having the minimum required stock is necessary. In dealing with this problem, the company is guided by previous experience, not in terms of intuition, but the analysis. By rational decision-making, the one analyzes previous businesses, makes a diagnosis and reviews alternatives, and ultimately, finds the optimal solution.

The budgeting starts from the following presumptions: the number of inventory units at the end of the month is in the amount of $80 \%$ of the planned sales for the next month, and the budgeted procurement costs per unit amounted to $€ 5$.

\section{Budget cost of sales}

Production and sales costs may be forecasted on the basis of the sales plan. There is a tie between the sales volume and sales cost budget, which is reflected in the fact that the sales budget is often corrected, if it turns out that the sales cost volume is inadequate. This is a form of rational decision-making, only the number of alternatives is reduced, because this budget is conditioned by the previous ones.

Travel agency

The budget cost of sales for July, August and September 2015.

\begin{tabular}{|c|c|c|c|c|}
\hline & July & August & September & Total \\
\hline $\begin{array}{l}\text { Budgeted sales } \\
\text { value }\end{array}$ & $€ 250.000$ & $€ 220.000$ & $€ 250.000$ & $€ 720.000$ \\
\hline $\begin{array}{l}\text { Provision of sales as } \\
\text { a percentage }\end{array}$ & $10 \%$ & $10 \%$ & $10 \%$ & $10 \%$ \\
\hline $\begin{array}{l}\text { Provision of sales in } \\
\text { dollars }\end{array}$ & $€ 25.000$ & $€ 22.000$ & $€ 25.000$ & $€ 72.000$ \\
\hline Manager's salary & 5.000 & 5.000 & 5.000 & 15.000 \\
\hline Total cost of sales & $€ 30.000$ & $€ 27.000$ & $€ 30.000$ & $€ 87.000$ \\
\hline
\end{tabular}

\section{Budget of general and administrative costs}

The budget of general and administrative costs depends, among other things, on the planned sales volume, which facilitates the decision-making process. However, it should be emphasized that the costs also depend on other factors, such as the company's business policy or environmental influences (e.g. inflationary movements). In this case, rational decisions are made based on the analysis of all impact factors. Such decision usually falls within the competences of general services manager.

The budgeting starts from the presumptions that annual administration earning is $€ 120,000$ and equipment depreciation is $€ 60,000$.

Travel agency

The budget in general and administrative expenses for July, August and September 2015.

\begin{tabular}{lcccc}
\hline & July & August & $\begin{array}{c}\text { Sep- } \\
\text { tember }\end{array}$ & Total \\
\hline $\begin{array}{l}\text { Earnings ad- } \\
\text { ministration }\end{array}$ & $€ 10.000$ & $€ 10.000$ & $€ 10.000$ & $€ 30.000$ \\
\hline $\begin{array}{l}\text { Equipment } \\
\text { depreciation }\end{array}$ & $€ 5.000$ & $€ 5.000$ & $€ 5.000$ & $€ 15.000$ \\
\hline
\end{tabular}




\section{FINANCIAL BUDGETS}

\section{Capital expenditure budget}

One of the requirements for the company's development and prospects is continuous accumulation and investment, no matter if it comes to the construction of new or reconstruction and modernization of the existing capacities, which achieves higher production, raises the quality of business, gains new products, increases productivity, shortens the production time, reduces production costs, achieves higher profits and employs new staff. Capital expenditure budget falls within long-term budgets, and therefore, relies less on the general budget, and more on the development prospects of the company. Thus, drafting of this budget requires scientific decisionmaking. Usually, the company drafts the budget by itself or by another company that monitors market trends and assesses investment viability.
In this case, the company's management plans to purchase equipment in August in the amount of $€ 100,000$, which will be covered by the cash budget.

\section{Cash budget}

Cash flow budget is drafted on the basis of previous budgets. A key decision is to determine the amount of cash at the company's disposal at the beginning of the month, which should be provided. This amount is determined on the basis of previous experience by determining the amount of money circulating within the company. All other budget items are fully dependent on the previously prepared operating budgets and capital expenditures budget. This budget enables the management to plan in advance the loan value to cover the possible lack of cash.

In the case of our travel agency, the cash budget is planned as follows:

Travel agency

The cash budget for July, August and September 2015.

\begin{tabular}{|c|c|c|c|}
\hline & July & August & September \\
\hline Opening balance of cash & $€ 100.000$ & $€ 100.000$ & $€ 100.000$ \\
\hline Profit in cash from customers & 275.000 & 235.000 & 235.000 \\
\hline Total & $€ 375.000$ & $€ 335.000$ & $€ 335.000$ \\
\hline \multicolumn{4}{|l|}{ Operating expenses in cash } \\
\hline Payouts & $€ 200.000$ & $€ 113.000$ & $€ 122.000$ \\
\hline Sales commissions & 25.000 & 22.000 & 25.000 \\
\hline Manager's earning & 5.000 & 5.000 & 5.000 \\
\hline Administration & 10.000 & 10.000 & 10.000 \\
\hline Income tax paid & 100.000 & & \\
\hline Dividends & & 10.000 & \\
\hline Bank loan interest rate & & 650 & 907 \\
\hline Procurement of equipment & & 100.000 & \\
\hline Total operating expenses & $€ 340.000$ & $€ 260.650$ & $€ 162.907$ \\
\hline Situation & $€ 35.000$ & $€ 74.350$ & $€ 172.094$ \\
\hline New bank loan & 65.000 & 25.650 & 0 \\
\hline Repayment of bank loan & & & $72.093,5$ \\
\hline Closing balance of cash & $€ 100.000$ & $€ 100.000$ & $€ 100.000$ \\
\hline Loan balance at the end of month & $€ 65.000$ & $€ 90.650$ & $€ 18.557$ \\
\hline
\end{tabular}


The budgeting starts from the following presumptions: initial cash balance is $€ 100,000,50 \%$ of sales in the previous period was cash sales, and the remaining $50 \%$ was credit sales, the profit of the loan is expected in the following month, the dividends for August amount to $€ 10,000$ and bank loan interest is $1 \%$ per month.

\begin{tabular}{lcccc}
\hline & June & July & August & September \\
\hline $\begin{array}{l}\text { Planned reali- } \\
\text { zation }\end{array}$ & $€ 300.000$ & $€ 250.000$ & $€ 220.000$ & $€ 250.000$ \\
\hline $\begin{array}{l}\text { \% credit sales } \\
\text { Amount of } \\
\text { credit sales }\end{array}$ & $€ \mathbf{1 5 0 . 0 0 0}$ & $€ \mathbf{1 2 5 . 0 0 0}$ & $€ \mathbf{1 1 0 . 0 0 0}$ & $€ \mathbf{1 2 5 . 0 0 0}$ \\
\hline $\begin{array}{l}\text { \% cash sales } \\
\text { Amount of cash }\end{array}$ & $50 \%$ & $50 \%$ & $50 \%$ & $50 \%$ \\
\hline $\begin{array}{l}\text { sales } \\
\text { Cash profit }\end{array}$ & & $€ 275.000$ & $€ 235.000$ & $€ 235.000$ \\
\hline
\end{tabular}

\section{Budgeted income statement}

Budgeted Income Statement summarizes the impacts of previous budgets. There is no decision-making at this phase, the statement presents the facts. Decisions in the budget have their own course of development in a manner that the most important decisions are made at the beginning of drafting the general budget, and as the budget develops, the required level of decision-making reduces, since it is moved on the techniques and effects of the decisions made. Once this procedure has been completed, it is necessary to check whether the settings are logical. Real business should be aligned with the drafted budget. Control, as part of the decision-making process, is present in this phase, which indicates whether there is a need for audit, i.e. the correction of operational budget. The audit, like the general budget development, starts from sales balance, reviewing the investment decisions.

\begin{tabular}{lc}
\hline \multicolumn{3}{c}{ Travel agency } \\
Budgeted Income Statement for three months ending \\
with September 30, 2015. \\
\hline Sale & $€ 720.000$ \\
\hline Cost of sale & 360.000 \\
\hline Gross profit & $€ 360.000$ \\
\hline Operating expenses: \\
\hline \multicolumn{3}{c}{ Commissions from sales } \\
\hline Salaries of employees in sales & 12.000 \\
\hline Earnings administration & 30.000 \\
\hline Equipment depreciation & 15.000 \\
\hline Interest expense & 1.557 \\
\hline Income before tax on turnover & $€ 226.444$ \\
\hline Income tax expense 40\% & $90.577,40$ \\
\hline & $€ \mathbf{1 3 5 . 8 6 6}$ \\
\hline
\end{tabular}

\section{Budgeted balance sheet}

Although the decision-making level decreases in the final phases of the general budget development - budgeted statements on income and balance sheet, the same could not be said for the phase of the company's budgeted activities implementation. After the general budget has been drafted, the task of the company's management is to, by rational and efficient decision-making, provide guidance and harmonisation of real business operations of the company's functional parts with its budgeted activities.

In this case, positive operating results are expected in the future, which can be determined according to the following budgeted balance sheet:

Travel agency

Budgeted balance sheet on September 30, 2015 .

\begin{tabular}{lclc}
\hline \multicolumn{2}{c}{ Assets } & \multicolumn{2}{c}{ Liabilities } \\
\hline Cash & $€ 100.000$ & Suppliers & $€ 105.000$ \\
\hline $\begin{array}{l}\text { Customers/ } \\
\text { clients }\end{array}$ & 125.000 & $\begin{array}{l}\text { Deferred } \\
\text { income tax }\end{array}$ & $90.577,4$ \\
\hline Inventories & 80.000 & $\begin{array}{l}\text { Bank loan } \\
\text { liabilities }\end{array}$ & 18.557 \\
\hline Equipment & $€ 600.000$ & $\begin{array}{l}\text { Ordinary } \\
\text { shares }\end{array}$ & $€ 400.000$ \\
\hline $\begin{array}{l}\text { Accumulat- } \\
\text { ed deprecia- } \\
\text { tion }\end{array}$ & $(115.000)$ & $\begin{array}{l}\text { Retained } \\
\text { earnings }\end{array}$ & 175.866 \\
\hline Total assets & $€ 790.000$ & $\begin{array}{l}\text { Total liabili- } \\
\text { ties }\end{array}$ & $€ 790.000$ \\
\hline
\end{tabular}

\section{CONCLUSION}

All of the aforementioned decision-making forms are present in everyday business management practices. In the broadest sense, their role is the achievement of business objectives. In order to realize those objectives, the management of a company must, among other things, carefully plan activities and forecast future conditions in which the company will operate. Budgeting is defined as management's quantitative expression of plans for the forthcoming period.

Different forms of decision-making on the general budget of the tourism organization for the purpose of improving the quality of tourism products are encountered in various phases of budget development. However, it could be said that rational decision-making plays the key role in this business segment. Other forms of decision-making, which the company applies in accordance with its financial and human resources, including time as a resource, should not be neglected. Scientific decision-making, which includes the application of 
mathematical and statistical methods and information technologies, requires more funds. On the other hand, some kind of intuitive decision-making is present in case the company evaluates the market on its own relying on the previous business experience. Various forms of decision-making are present in the final phase of the general budget, when new decisions are made on the basis of the budgeted balance sheet, which determines the further business policy of the company, i.e. whether the proposed budget will be accepted or audited.

\section{REFERENCES}

Čerović, S., \& Spasić, V.(2013). Ekonomsko-finansijska analiza poslovanja preduzeća u hotelijerstvu i turiz$m u$. Beograd: Univerzitet Singidunum.

Kickert, W.J.M. (1980). Organisation of Decision Making: A System-Theoretical Approach. Amsterdam: North Holland Publishing Company.

Stanišić, M., \& Radović, N. (2011). Operativno budžetiranje i kontrola sa aspekta poslovanja hotelskog preduzeća. Strategic management: international journal of strategic management and decision support systems in strategic management, 16(2), 1.

Zečević, M., \& Nedeljković, D. (2000). Menadžersko odlučivanje. Beograd: Fakultet za internacionalni menadžment. 